\title{
Doses from Cs-137 and Sr-90 to Czech population due to milk consumption
}

\author{
M. Bartusková ${ }^{1 *}$, J. Škrkal ${ }^{2}$, E. Schlesingerová ${ }^{2}$, V. Bečková ${ }^{2}$ and I. Malátová ${ }^{2}$ \\ ${ }^{1}$ NRPI, branch Ostrava, Syllabova21, 70300 Ostrava 3, Czech Republic. \\ 2 NRPI, Bartoškova21, 14000 Praha 4, Czech Republic.
}

Received: 3 June 2016 / Accepted: 3 May 2017

\begin{abstract}
Activity concentrations of ${ }^{137} \mathrm{Cs}$ and ${ }^{90} \mathrm{Sr}$ in milk have been monitored in the Czech Republic on a long-term basis. The annual geometric means of ${ }^{137} \mathrm{Cs}$ activity concentrations in milk range from $12 \mathrm{~Bq} . \mathrm{L}^{-1}$ in 1986 to $0.02 \mathrm{~Bq} . \mathrm{L}^{-1}$ in 2014 . The annual geometric means of ${ }^{90} \mathrm{Sr}$ activity concentrations range from $0.69 \mathrm{~Bq} . \mathrm{L}^{-1}$ in 1965 to $0.02 \mathrm{~Bq} . \mathrm{L}^{-1}$ in 2014 . The values of effective and environmental halflives in milk were calculated for both radionuclides from the annual geometric means and their temporal trends. Doses from both radionuclides due to milk ingestion were estimated.
\end{abstract}

Keywords: ${ }^{137} \mathrm{Cs}$ caesium $/{ }^{90} \mathrm{Sr}$ strontium / milk / dose

\section{Introduction}

The content of radionuclides in milk has been a subject of long-term monitoring in the Czech Republic. The most important artificial radionuclides in the food chain are ${ }^{137} \mathrm{Cs}$ and ${ }^{90} \mathrm{Sr}$. Both have long physical half-life, both are chemical analogues of biogenic elements and both are transferred to milk. Caesium-137 with a half-life of 30.1 years, is an analogue of potassium depositing in muscular tissue and its behaviour is similar to potassium in plants and animals. Strontium has similar half-life, 28.8 years and behaves very much like calcium. A large portion of strontium will accumulate in bones and like calcium it transfers to milk. Since the Sr uptake by the human body from milk is an important pathway for radiostrontium incorporation, milk is a good indicator of ${ }^{90} \mathrm{Sr}$ content in human diet.

${ }^{137} \mathrm{Cs}$ and ${ }^{90} \mathrm{Sr}$ in the environment of the Czech Republic came from two sources. The first source has been relatively homogeneous surface contamination caused by the nuclear weapon tests especially in the 1960s. It used to reach (UNSCEAR, 1982) $5 \mathrm{kBq} \cdot \mathrm{m}^{-2}$ for ${ }^{137} \mathrm{Cs}$ and $3.23 \mathrm{kBq} \cdot \mathrm{m}^{-2}$ for ${ }^{90} \mathrm{Sr}$ on the north hemisphere between $40^{\circ}-50^{\circ} \mathrm{N}$. The second source was surface contamination caused by the fallout after the Chernobyl nuclear power plant accident. It spread inhomogeneously on the Czech Republic territory due to the variedly intensive rainfalls during the passage of the contaminated air over the territory. After the Chernobyl accident maximal surface activities of ${ }^{137} \mathrm{Cs}$ in some areas reached up to $100 \mathrm{kBq} \cdot \mathrm{m}^{-2}$; the average value was estimated (IHE, 1986; UNSCEAR, 1993; De Cort et al., 1998) to be between 4 and $7 \mathrm{kBq} \cdot \mathrm{m}^{-2}$. Concerning ${ }^{90} \mathrm{Sr}$, the activity increment in Central Europe caused by the

\footnotetext{
* Corresponding author: miluse. bartuskova@sujb.cz
}

Chernobyl accident was several times lower (Irlweck and Khademi, 1996; De Cort et al., 1998) than that of ${ }^{137}$ Cs.

As a result of the Chernobyl accident in 1986 the activity concentrations of ${ }^{137} \mathrm{Cs}$ in milk in many countries increased markedly by two to three orders from less than a tenth of $\mathrm{Bq} \cdot \mathrm{L}^{-1}$ to units up to tens of Bq. $\mathrm{L}^{-1}$. The activity concentrations decreased relatively quickly during approximately a decade back to the pre-Chernobyl value. The decrease in the following years was only very slow (Grabowski et al., 2002; Varga et al., 2006; STUK, 2008; JRC, 2009). The development of ${ }^{137} \mathrm{Cs}$ activity concentrations in milk in the Czech Republic in the first years after the Chernobyl accident is described in several publications (Drábová et al., 1988, 1990; Kameník et al., 2009). The comprehensive results of milk and powdered milk monitoring till 2014 are presented in this paper.

The following values of ${ }^{90} \mathrm{Sr}$ activity concentrations in milk were detected in several countries neighbouring the Czech Republic: Poland - 0.3 Bq.L $\mathrm{L}^{-1}$ in 1974 and 0.2 Bq.L ${ }^{-1}$ in 1975; East Germany - between 1974 and 1976 the values were in the interval $(0.2-0.1) \mathrm{Bq} . \mathrm{L}^{-1}$; West Germany - the values (UNSCEAR, 1982) between 1975 and 1980 were in the interval (0.3-0.1) Bq.L $\mathrm{L}^{-1}$. In Austria 0.078 Bq. $\mathrm{L}^{-1}$ was found (Mück et al., 1990) in 1997. Already in the period of the nuclear weapon tests the content of ${ }^{90} \mathrm{Sr}$ in the Czech Republic environment had been monitored (Březík et al., 1980; Radioaktivita, 1990).

\section{Materials and methods}

\subsection{Sampling of milk}

Samples of raw, processed - pasteurised, sterilised and powdered milk come in the Radiation monitoring network 
(RMN) from the retail network or producers (mostly dairies) for ${ }^{137} \mathrm{Cs}$ and ${ }^{90} \mathrm{Sr}$ determination. The aim is to achieve the most widespread and homogeneous monitoring of the Czech Republic territory and consequently to detect representative activities, which allow to estimate the population doses. Since the Chernobyl accident till the present time the sampling has been optimized as activities of radionuclides kept decreasing. Several tens of liquid and powdered milk samples from virtually homogeneously spread sites are collected in the Czech Republic per year.

Altogether 8107 samples of milk were collected within RMN since the Chernobyl accident till the end of 2014 for determination of ${ }^{137} \mathrm{Cs}$. Out of the number there were 5350 liquid milk samples and 2757 powdered milk samples. Besides the National Radiation Protection Institute, the State Veterinary Institute has been participating in the milk sampling and ${ }^{137} \mathrm{Cs}$ evaluation since 2004 . The results are collected in the common database RMN.

For the period 1965 - spring 1986 annual geometric means of ${ }^{90} \mathrm{Sr}$ activity are included in this study. Data on ${ }^{90} \mathrm{Sr}$ activity concentrations in milk from dairy (Praha - Radlice) since 1965 till 1995 are available. Samples for ${ }^{90} \mathrm{Sr}$ determination were collected systematically only in that dairy till 1986, afterwards the sampling network was enlarged markedly. Results from seven dairies in Northern Moravia and several others in Prague and its vicinity are used in this paper. Some of the dairies have been closed and the activity concentration of ${ }^{90} \mathrm{Sr}$ in liquid milk decreased, therefore the number of surveyed dairies was reduced. The dairy sampling was conducted in Prague till 2002, followed by liquid milk sampling from retail shops until now. In Northern Moravia one dairy: Ostrava Martinov, has been surveyed since 1988-till present, with quarterly sampling. Three hundred and sixty four data on liquid milk have been obtained since 1986 .

Since activity concentrations of ${ }^{90} \mathrm{Sr}$ in liquid milk were decreasing, determinations of its activity concentrations in powdered milk were initiated. The samples have been collected from one dairy since 1999 and from retail network in seven regions of the Czech Republic since 2006, currently 2 times a year. Altogether 173 powdered milk samples have been analysed since 1999.

\subsection{Caesium-137 detection with gamma-ray spectrometry}

Caesium-137 is detected using gamma-ray spectrometry, either with or without the sample pre-treatment. High purity germanium detectors of various efficiencies ranging from 10 to $150 \%$ were used. The efficiency calibration with gel calibration standards produced in the Czech Metrology Institute was used. In case of the difference between the measured sample density and calibration standard, correction to self-absorption was performed.

Activity of ${ }^{137} \mathrm{Cs}$ in powdered milk samples, and, less often, in liquid milk samples, was measured without previous treatment in identical geometry in cylindrical containers of $0.2 \mathrm{~L}$ placed around or on the detector. In samples of liquid milk with low activity concentration, ${ }^{137} \mathrm{Cs}$ was separated before the counting with composite inorganic ion exchanger NiFC-PAN, produced (Šebesta et al., 1994) at the Czech Technical University and after drying measured in Petri dishes of $55 \mathrm{~mm}$ diameter. To calculate statistical characteristics, ${ }^{137} \mathrm{Cs}$ activity of powdered milk (in Bq. $\mathrm{kg}^{-1}$ ) was converted into activity concentrations of liquid milk (in Bq. $\mathrm{L}^{-1}$ ) by dividing by the following factors: $11.2 \mathrm{~L} . \mathrm{kg}^{-1}$ (skimmed milk with lower than $0.5 \%$ fat on dry basis), $9.8 \mathrm{~L} \cdot \mathrm{kg}^{-1}$ (semi skimmed milk with $14 \%$ fat) and 8.2 or $8.4{\mathrm{~L} . \mathrm{kg}^{-1}}^{-}$(whole milk with 26 and 28\% fat) (Kněz, 1974). In case there was no fat indication on the given sample of powdered milk, the conversion factor for semi skimmed milk was used.

\subsection{Radiochemical determination of ${ }^{90} \mathrm{Sr}$}

Activity of ${ }^{90} \mathrm{Sr}$ in liquid and powdered milk has been monitored exploiting a radiochemical method based on the U.S. Department of Energy, Environmental Measurements Laboratory method Sr-03-RC (HASL 300, 2015). Contrary to the original method strontium was not separated from calcium. A milk sample was ashed and the ash dissolved in hydrochloric acid. First, strontium and calcium were concentrated by oxalate precipitation. Radium, lead and barium were removed with barium chromate precipitation. Traces of other fission products were scavenged with iron hydroxide. After the ${ }^{90} \mathrm{Sr}+{ }^{90} \mathrm{Y}$ equilibrium has been attained, yttrium was precipitated as the hydroxide and converted to the oxalate for counting on a lowbackground gas-flow proportional beta counter. The source was repeatedly measured, typically for a week to follow the decrease in ${ }^{90} \mathrm{Y}$ activity. Activity of ${ }^{90} \mathrm{Sr}$ was calculated from the measured data and the time of ${ }^{90} \mathrm{Y}$ ingrowth. Strontium yield was determined with ${ }^{85} \mathrm{Sr}$ tracer by counting in a gamma well detector. The separation yield of $Y$ was determined by complexometric titration. Efficiency of the proportional counter for ${ }^{90} \mathrm{Y}$ was determined by counting ${ }^{90} \mathrm{Y}$ separated from a standard solution the same way as in sample analysis.

Various types of low-background alpha-beta instruments with proportional detectors were being used in the whole period. All the chemicals used in the analyses were of analytical grade.

When liquid milk was used, samples from 2 to $3.5 \mathrm{~L}$ were taken and divided into two parallel sub-samples. Tracer ${ }^{85} \mathrm{Sr}$ was added directly to the milk. When powdered milk was used, typically samples of $0.4 \mathrm{~kg}$ were taken for the analysis and tracer ${ }^{85} \mathrm{Sr}$ was added to the ash. For powdered milk the value of activity in the powdered milk was recalculated for the activity concentration in native state using factor of $9.8 \mathrm{~L} \cdot \mathrm{kg}^{-1}$.

\subsection{Statistical data processing}

When processing the results, statistical characteristics of the individual data sets for ${ }^{137} \mathrm{Cs}$ and ${ }^{90} \mathrm{Sr}$ activities in milk were calculated from the individual values from all the sampling locations. Arithmetic mean (AM), geometric mean (GM) and geometric standard deviation (GSD) were estimated using programme $\mathrm{R}$ and a set of statistical programmes (Lee, 2009; R Development Core Team, 2011) NADA, which allow to evaluate data sets containing lower than minimum significant activity (MSA) values (Currie, 1968) and create their model substitutes. The calculations were based on the assumption of a log-normal distribution of the detected activities, while the MSA values were substituted with the model values, to comply with the assumption of the data log-normality as much as possible. The log-normality data compliance was verified by projection in quantile plots. 


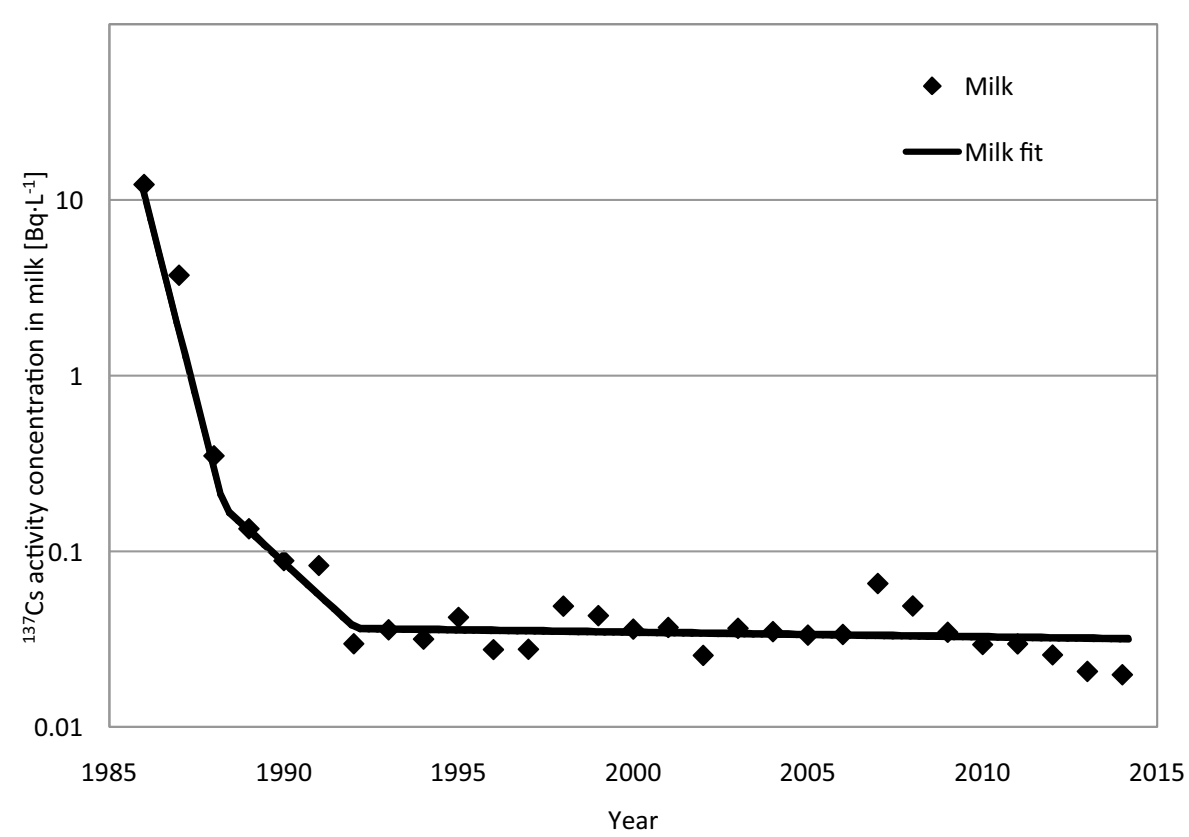

Fig. 1. The annual geometric means of ${ }^{137} \mathrm{Cs}$ activity concentrations in milk in the whole Czech Republic.

\subsection{Calculation of half-lives and doses}

Generating a best fit of time curve from radionuclide activity values in the matrix enables determination of effective and environmental half-lives of a given radionuclide in the given matrix. Effective half-life $T_{E F}$ characterizes a decrease in content caused by all processes in progress in a natural ecosystem in the given period and it is determined by equation (1):

$$
T_{E F}=\frac{\ln 2}{\lambda_{E F}},
$$

in which $\lambda_{E F}$ means effective rate of loss. Environmental halflife $T_{E N}$ characterizes a decrease in a radionuclide activity caused by all processes being in progress in a natural ecosystem except for radioactive decay. Environmental halflife $T_{E N}$ can be expressed by equation (2):

$$
T_{E N}=\frac{\left(T_{E N} \times T_{P}\right)}{T_{P}-T_{E F}}
$$

in which $T_{P}$ is physical half-life of the given radionuclide, while it is always valid, that $T_{P}>T_{E F}$.

Logarithmic plots of all the geometric means were created for each radionuclide. The activity time courses of both radionuclides show different characters in various periods. The whole observed intervals were thus divided into segments characterized by straight data development as presented in the logarithmic plot. The location of the break points for ${ }^{137} \mathrm{Cs}$ was determined by iteration method (Muggeo, 2003). The fits and resulting equations in the individual sections were obtained by piecewise linear continuous regression implemented in the package "segmented" of the programme R (Muggeo, 2008).

For ${ }^{90} \mathrm{Sr}$, at first the whole monitored interval was also analysed with the help of the above mentioned iteration method. It suggested the break points in the years 1974 and 1991. As especially the second suggested break did not correspond to the events important from the point of view of the radionuclide release into the environment, a different way of evaluation was chosen. The new break points at 1974 and 1986 were determined. Linear regression in Excel application was used to obtain the best fits for the chosen segments. Values of $\lambda_{E F}$ (actually a slope of the best fit lines) and their deviations were calculated for the individual segments. According to equation (1) effective and according to equation (2) environmental half-lives were calculated for both radionuclides in the given periods.

Annual committed effective dose, $E$, was estimated using equation (3):

$$
E=G M(c) \times C R \times h_{\text {ing }},
$$

in which $G M(c)$ means geometric mean of activity concentration, $C R$ consumption rate of raw milk (in equivalent of milk products) and $h_{\text {ing }}$ dose coefficient for intake by ingestion.

\section{Results and discussion}

\subsection{Caesium-137}

Since 1986 the number of annually analysed samples was gradually reduced from the original 3046 to 66 in 2014. In the same time interval the number of model (below MSA) values increased from $5 \%$ to $50 \%$. As for the individual values of ${ }^{137} \mathrm{Cs}$ activity concentrations the maximum value in 1986 in one of the sampling locations 560 Bq. $\mathrm{L}^{-1}$ was found. In 2014 no activity concentration exceeded $0.3 \mathrm{~Bq} \cdot \mathrm{L}^{-1}$.

Annual GMs of ${ }^{137} \mathrm{Cs}$ activity concentrations in milk are shown in Figure 1. Time course of ${ }^{137} \mathrm{Cs}$ activity concentrations in milk starts with the GM of $12 \mathrm{~Bq} . \mathrm{L}^{-1}$ in 1986. Rapid decrease in the first years after the Chernobyl accident was 
Table 1. Regression equation of the curves and the values of the effective $\left(T_{E F}\right)$ and environmental $\left(T_{E N}\right)$ half-lives of ${ }^{137} \mathrm{Cs}$ in milk in the Czech Republic between 1986 and 2014 calculated from them.

\begin{tabular}{|c|c|c|c|}
\hline \multicolumn{4}{|c|}{${ }^{137} \mathrm{Cs}$ in milk - whole CR } \\
\hline Years & 1986-1988 & 1989-1992 & $1992-2014$ \\
\hline Break [year] & 0 & $2.6 \pm 0.1$ & $6.4 \pm 0.3$ \\
\hline Equation & $\mathrm{y}=19.3 \mathrm{e}^{-1.8 \mathrm{x}}$ & $y=0.53 \mathrm{e}^{-0.42 \mathrm{x}}$ & $\mathrm{y}=0.038 \mathrm{e}^{-0.0061}$ \\
\hline$\lambda_{E F}\left[\right.$ year $\left.^{-1}\right]$ & $1.80 \pm 0.30$ & $0.42 \pm 0.05$ & $0.006 \pm 0.003$ \\
\hline$T_{E F}[$ year $]$ & 0.4 & 1.7 & $\mathrm{n} / \mathrm{a}$ \\
\hline$T_{E N}[$ year $]$ & 0.4 & 1.8 & $\mathrm{n} / \mathrm{a}$ \\
\hline
\end{tabular}

approximately from 1992 followed with almost constant development of activity concentrations on the level of hundredths of Bq.L ${ }^{-1}$ and the minimum value is $0.02 \mathrm{~Bq} . \mathrm{L}^{-1}$ in 2014. The GSDs for annual GMs for the whole interval 1986-2014 were about from 2 to 4.

The values of ${ }^{137} \mathrm{Cs}$ activity concentrations were used to generate a best fit curve starting at the day of the Chernobyl accident (26 April 1986). Using programme R, the first break point on the curve to $(2.6 \pm 0.1) \mathrm{y}$ and the second break point $(6.4 \pm 0.3)$ y after the accident was determined. As the first and the second segments are very short, with a small number of the annual GMs, individual measured activities and model values to find the fits for all three segments were used.

The best fit equations of the curves and effective $\left(T_{E F}\right)$ and environmental $\left(T_{E N}\right)$ half-lives calculated from them are presented in Table 1 . The activity concentrations were decreasing from 1986 to 1988 with the $T_{E F}=0.4 \mathrm{y}$ and $T_{E N}=0.4 \mathrm{y}$ $\left(\lambda_{E F}=[1.80 \pm 0.30] \mathrm{y}^{-1}\right)$. Between 1989 and 1992 the decrease slowed and both half-lives increased to $T_{E F}=1.7 \mathrm{y}$ and $T_{E N}=1.8 \mathrm{y}\left(\lambda_{E F}=[0.42 \pm 0.05] \mathrm{y}^{-1}\right)$. Since 1992 the level of ${ }^{137} \mathrm{Cs}$ activity concentration in milk has been stable. The effective half-life has not been calculated because it does not comply with the condition $T_{P}>T_{E F}$. Estimation of the coefficient $\lambda_{E F}$ is in this case loaded with high uncertainty (approximately $50 \%, \lambda_{E F}=[0.006 \pm 0.003] \mathrm{y}^{-1}$ ) caused by its low level and a relatively short observation interval.

For comparison, in Austria the environmental half-life values for ${ }^{137} \mathrm{Cs}$ in milk were found to be $4.5 \mathrm{y}-15 \mathrm{y}$ in the period 1988-2007 and 4.3y - 29.9y for the shorter period 19932007. Both half-lives markedly depend (Lettner et al., 2009) on the altitude where cows live. According to other sources the reduction of ${ }^{137} \mathrm{Cs}$ content in dairy milk in four variedly contaminated areas in Finland was slower than in the Czech Republic and different in unevenly contaminated areas. The environmental half-life values there were estimated (Kostiainen, 2005 ) to be $1.8 \mathrm{y}-3.2 \mathrm{y}$ in the period $1987-1989$ and $4.7 \mathrm{y}-8.7 \mathrm{y}$ for the period 1990-2003. For milk sampled in 1987-1993 from ten farms in central Sweden the effective half-life was in the interval $0.8 \mathrm{y}-2 \mathrm{y}$ (Gunnel et al., 1995). Only a rough comparison of the values found by us and the values published is possible because individual papers differ in the survey period length and the number of break points on the best fit curves.

\subsection{Strontium-90}

Since 1965 altogether 537 milk samples were analysed in the whole Czech Republic. Out of that $19 \%$ were lower than the MSA. The number of samples increased after the Chernobyl accident in 1986, in the period 1986-1996 approximately 40 milk samples were analysed annually. No value was under MSA in this period. Since 1997 the number of samples has been optimised and gradually reduced to 14 samples per year in 2014. Since 2008 some single and later most values have been under MSA, altogether $64 \%$ of values in 2014.

Calculated annual geometric means of ${ }^{90} \mathrm{Sr}$ activity concentrations in milk fitted with a curve are presented in Figure 2. The highest activity concentration of ${ }^{90} \mathrm{Sr}$ in milk comes from 1965 and equals to $0.69 \mathrm{~Bq} . \mathrm{L}^{-1}$, in the following years first a sharp and from 1971 a slow decrease were observed. It is evident from the plot (Fig. 2) that ${ }^{90} \mathrm{Sr}$ activity concentration in milk promptly decreased after the atmospheric nuclear test moratorium (UNSCEAR, 1982) in 1963 (France signed in 1974, China did not sign). The decrease was caused by lower release of ${ }^{90} \mathrm{Sr}$ into the environment and its consequent transfer to the dairy milk cows and their milk. In 1986 due to the Chernobyl accident ${ }^{90} \mathrm{Sr}$ was further released into the environment, which resulted in an abrupt increase in $\mathrm{GM}$ values from $0.06 \mathrm{~Bq} . \mathrm{L}^{-1}$ to $0.10 \mathrm{~Bq} . \mathrm{L}^{-1}$ in the Czech Republic. As a consequence, the number of sampling sites and milk samplings were extended. Calculated GMs in the following years were thus loaded with higher uncertainty due to larger dispersion of the detected values. From the new maximum in 1986 the activity concentrations were decreasing and after approximately 10 years they reached the values observed before the Chernobyl accident, approximately $0.06 \mathrm{~Bq} . \mathrm{L}^{-1}$. Such a time course corresponds well to the activity concentrations found in the neighbouring states, mentioned earlier in the first chapter.

For ${ }^{90} \mathrm{Sr}$, programme $\mathrm{R}$ suggested the break points in $(9.3 \pm 0.9) \mathrm{y}$ and in $(26.7 \pm 3.3) \mathrm{y}$ from the beginning in 1965 , hence in the years 1974 and 1991. Comparing the suggestion of the programme with the course of events controlling ${ }^{90} \mathrm{Sr}$ content in the environment, it was found that the programme could not work appropriately with the abrupt, yet small increase in 1986 due to the Chernobyl accident. Therefore, the years 1974 (connection with the atmospheric nuclear test moratorium) and 1986 (the Chernobyl accident) were selected as the break points for the curves and further fits were conducted manually via linear regression in Microsoft Excel. The resulting regression equations of the curves and $T_{E F}$ and $T_{E N}$ calculated based on them are presented in Table 2.

\subsection{Estimation of doses}

The consumption rate of milk and milk products in terms of milk equivalent in Czech Republic is known (ČSÚ, 2012, 2014) for years 1965-2014, with average about 218 L. (year. person $)^{-1}$, minimal value 179.3 L. (year.person) ${ }^{-1}$ and maximal value 252.0 L. (year.person) $)^{-1}$.

The data for ${ }^{137} \mathrm{Cs}$ content in milk before Chernobyl accident do not exist and only rough estimation is possible based on UNSCEAR data (UNSCEAR, 1977). Maximal $\mathrm{GM}$ for ${ }^{137} \mathrm{Cs}$ activity concentration was determined in the year 1986. For adult population with dose coefficient (ICRP Publication 119, 2012) $1.3 .10^{-8} \mathrm{~Sv}^{-B_{q}}{ }^{-1}$ annual committed effective dose $26 \mu$ Sv.year ${ }^{-1}$ was calculated using equation (3). Since then, annual doses decreased stepwise to about $0.065 \mu$ Sv.year ${ }^{-1}$. 


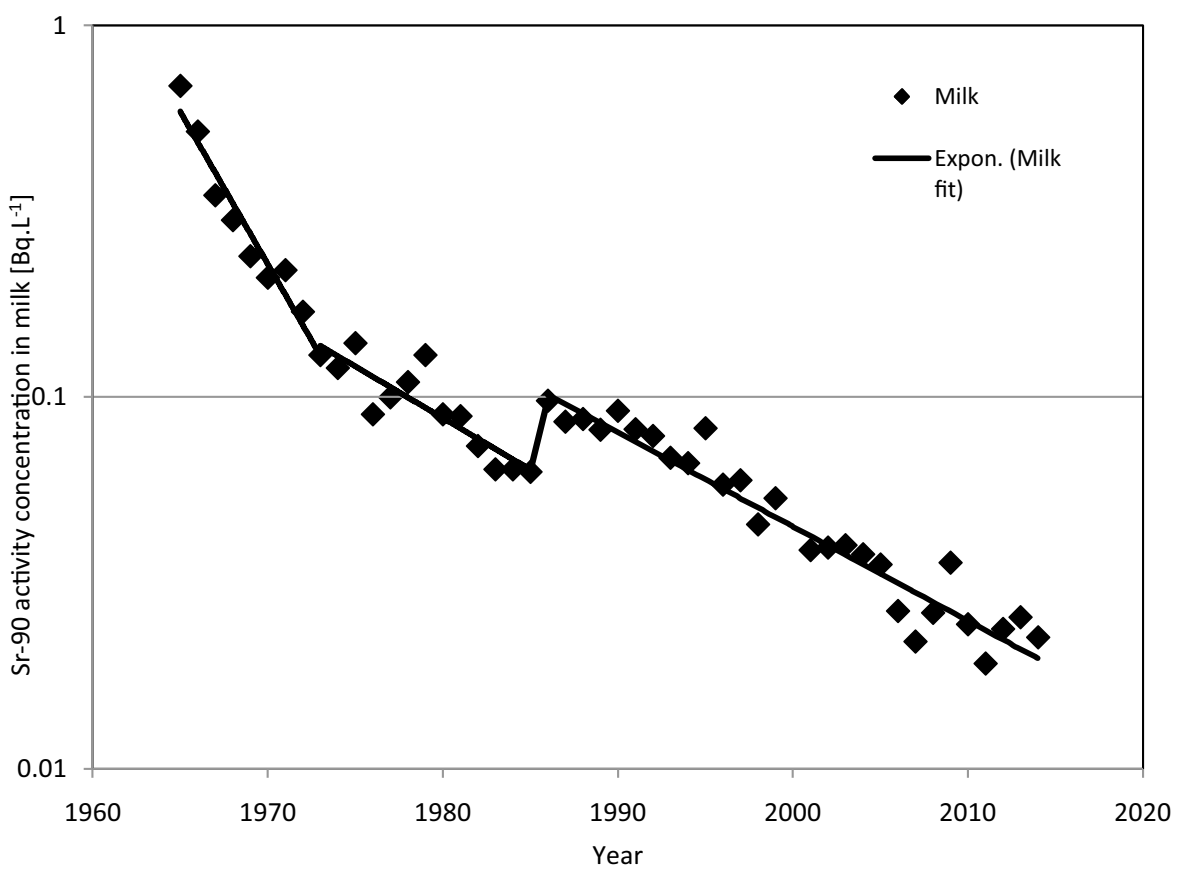

Fig. 2. The annual geometric means of ${ }^{90} \mathrm{Sr}$ activity concentrations in milk in the Czech Republic.

Table 2. Regression equation of the curves and the values of the effective $\left(T_{E F}\right)$ and environmental $\left(T_{E N}\right)$ half-lives of ${ }^{90} \mathrm{Sr}$ in milk between 1965-2013.

\begin{tabular}{llll}
\hline${ }^{90} \mathrm{Sr}$ in milk - whole CR & & \\
\hline Years & $1965-1973$ & $1974-1985$ & $1986-2013$ \\
Point "0" in year 1965 & 1974 & 1986 \\
Equation & $\mathrm{y}=0.59 \mathrm{e}^{-0.189 x} \mathrm{y}=0.14 \mathrm{e}^{-0.067 \mathrm{x}} \mathrm{y}=0.10 \mathrm{e}^{-0.058 \mathrm{x}}$ \\
$\lambda_{E F}$ [year $\left.{ }^{-1}\right]$ & $0.19 \pm 0.02$ & $0.07 \pm 0.01$ & $0.06 \pm 0.01$ \\
$T_{E F}$ [year] & 3.7 & 10.3 & 12.1 \\
$T_{E N}$ [year] & 4.2 & 16.2 & 20.4 \\
\hline
\end{tabular}

Due to maximal GM for ${ }^{90} \mathrm{Sr}$ activity concentration in milk, $0.69 \mathrm{~Bq} . \mathrm{L}^{-1}$, the highest annual dose from ${ }^{90} \mathrm{Sr}$ ingestion of milk was in the year 1965 , namely $4.2 \mu \mathrm{Sv}_{\text {.year }}{ }^{-1}$ for adult population (dose coefficient (ICRP Publication 119, 2012)

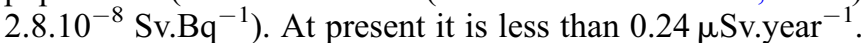

As the contamination of Czech territory after the Chernobyl accident was not homogeneous and there are also groups of people with higher consumption rate of milk and milk products, individual doses could also be higher up to one order of magnitude. Doses to small children were also higher. Apart of this, it has to be born in mind that after the Chernobyl accident, dominant contributors to ingestion doses from milk were radioisotopes of iodine and also ${ }^{134} \mathrm{Cs}$ contributed significantly.

\section{Conclusions}

The activity concentration mean of ${ }^{137} \mathrm{Cs}$ in milk in the Czech Republic decreased from 12 Bq.L ${ }^{-1}$ below 0.5 Bq. $\mathrm{L}^{-1}$ during three years after the Chernobyl accident and since then it has remained on very low level. Since 1990 GM of activity concentrations of ${ }^{137} \mathrm{Cs}$ in milk appear under the level of
0.1 Bq. $\mathrm{L}^{-1}$ and since 1992 the content of ${ }^{137} \mathrm{Cs}$ in the forage components and hence in milk is stable except for the decrease caused by radioactive decay.

Activity concentrations of ${ }^{90} \mathrm{Sr}$ in milk have dropped from initial tenths Bq.L $\mathrm{L}^{-1}$ to hardly detectable values during 19652014. Environmental and effective half-lives were calculated for the periods 1965-1973, 1974-1985 and 1986-2014, which are essential from the point of view of ${ }^{90} \mathrm{Sr}$ contamination. All $T_{E F}$ and $T_{E N}$ are lower than the physical half-life of ${ }^{90} \mathrm{Sr}$, so the radionuclide disappears from milk faster than due to its physical decay. The effective and environmental half-lives are very close in the second and the third monitoring periods - the possible explanation is a low share of ${ }^{90} \mathrm{Sr}$ contained in the environment in the Czech Republic due to the Chernobyl accident, compared to the whole amount of ${ }^{90} \mathrm{Sr}$.

The tests of nuclear weapon can be considered the largest source of man-made radionuclides in the environment in the Czech Republic.

The annual doses from ingestion of ${ }^{137} \mathrm{Cs}$ and ${ }^{90} \mathrm{Sr}$ are small. However, knowledge of the time course of activity of long-lived radionuclides in milk is important from the view of possible increases following irregular releases of radionuclides into environment.

Acknowledgement. This work was supported by Project of Ministry of Interior of the Czech Republic MV-25972-39/ OBVV- 2010. We acknowledge the State Office for Nuclear Safety for the possibility to exploit the data obtained within the frame of the Radiation Monitoring Network.

\section{References}

Březík Z, Březíková D, Kunz E. 1980. Vývoj zátěže obyvatelstva Sr$90 \mathrm{z}$ radioaktivního spadu. In: Vývoj obsahu ${ }^{90} \mathrm{Sr} v$ potravinách $v$ ČSR (Závěrečná etapová zpráva), Díl 2. Praha: Institut hygieny a epidemiologie, in Czech. 
Currie LA. 1968. Limits for qualitative detection and quantitative determination. Anal. Chem. 40: 586-593.

ČSÚ. 2012. Spotřeba potravin - 1948-2012. Available on: https:// www.czso.cz/csu/czso/spotreba-potravin-1948-az-2012-nhjw8eg93rj, in Czech.

ČSÚ. 2014. Food Consumption - 2014. Available on: https://www. czso.cz/csu/czso/food-consumption-2014.

De Cort M, et al. 1998. Atlas of cesium deposition on Europe after the Chernobyl accident. Brussels-Luxemburg: Office for Official Publications of the European Communities, ECSC-EEC-EAEC.

Drábová D, Rulík P, Malátová I, Bučina I, Hölgye Z. 1988. Výsledky celostátního pruzkumu obsahu umělých radionuklidu v mléce po černobylské havárii. Některé výsledky monitorování následku černobylské havárie v ČSSR. Praha: Ústřední informační středisko pro jaderný program, in Czech.

Drábová D, Rulík P, Malátová I, Bučina I, Holgye Z. 1990. Monitoring of fallout radionuclides in milk in Czechoslovakia after the Chernobyl accident. In: Environmental contamination following a major nuclear accident, October 16-20, 1989, IAEA Vienna Proceedings of a Symp., Vol. 2., pp. 93-96. Vienna: IAEA.

Grabowski D, Kurowski W, Muszyński W, Rubel B, Smagała G, Świętochowska J. 2002. Radioactivity of the environment and food in Poland in 2000-2001. Report of CLOR 2000-2001. Warsaw: Central Laboratory for Radiological Protection, 76.

Gunnel K, Johanson KJ, Bertilsson J. 1995. Transfer of ${ }^{137} \mathrm{Cs}$ to cow's milk: investigations on dairy farms in Sweden. J. Environ. Radioact. 28(1): 1-15.

HASL 300. 2015. 28th Edition. EML (1997). Available on: https:// www.orau.org/ptp/PTP\%20Library/library/DOE/eml/hasl300/ana lyticalchem.pdf.

ICRP Publication 119. 2012. Compendium of dose coefficients based on ICRP publication 60. Ann. ICRP 41(Suppl.).

IHE. 1986. Report on radiation situation in CSSR after Chernobyl accident. Prague: IHE.

Irlweck K, Khademi B. 1996. Radionuclide ratios of ${ }^{90} \mathrm{Sr} /{ }^{137} \mathrm{Cs}$ and ${ }^{239(240)} \mathrm{Pu} /{ }^{137} \mathrm{Cs}$ in contaminated surface air after the Chernobyl accident in Austria. J. Radioanal. Nucl. Chem. 1: 79-85.

JRC. 2009. Environmental radioactivity in the European Community 2004-2006. In: DG TREN: Nuclear energy, Radiation Protection (Luxembourg). European Commission, Joint Research CenterJRC, Institute for Environment and Sustainability, Ispra (Italy).
Kameník J, Škrkal J, Rulík P. 2009. Long term monitoring of Cs-137 in foodstuffs in the Czech Republic. Appl. Radiat. Isot. 67(5): 974-977.

Kněz V. 1974. Diary Guide - Tables and calculations. 1. Ed. Praha: SNTL, in Czech.

Kostiainen E. 2005. Ecological half-lives of ${ }^{137} \mathrm{Cs}$ and ${ }^{90} \mathrm{Sr}$ in dairy milk in regions with different soil types. Radioprotection 40 (1): S391-S397.

Lee L. 2009. NADA: Nondetects and data analysis for environmental data, R package version 1,5-2. CRAN.R-project, org/package=NADA.

Lettner H, Hubmer A, Bossew P, Strebl F, Steinhäusler F. 2009. Effective and ecological half-lives of ${ }^{137} \mathrm{Cs}$ in cow's milk in alpine agriculture. Radiat. Environ. Biophys. 48: 47-56.

Muggeo VMR. 2003. Estimating regression models with unknown break-points. Stat. Med. 22(19): 3055-3057.

Muggeo VMR. 2008. Segmented: an R package to fit regression models with broken-line relationships. $R$ News 8(1): 20-25.

Mück K, Streit S, Steger F, Mayr K, Karg V. 1990. Estimate of the dose due to ${ }^{90} \mathrm{Sr}$ to the Austrian population after the Chernobyl accident. Health Phys. 38: 47-58.

R Development Core Team. 2011. R. A language and environment for statistical computing. Available on: www.R-project.org.

Radioaktivita. 1990. In: Životni prostředi České republiky (Vývoj a stav do konce roku 1989), pp. 183-199. Praha: Academia, in Czech.

STUK. 2008. Surveillance of environmental radiation in Finland, Annual report 2007 (R. Mustonen, Ed.), STUK-B 91. Helsinki, p. 67. ISBN 978-952-478-380-4 (pdf). Available on: www.stuk.fi.

Šebesta F, John J, Motl A. 1994. Separation and concentration of contaminants using inorganic-organic composite absorbers. In: Budapest'94 - 2nd Symposium and Exhibition on Environmental Contamination in Central and Eastern Europe, Proceedings, September 20-23, Budapest.

UNSCEAR. 1977. Sources and effects of ionizing radiation. In: Report to the General Assembly, with annexes. United Nations, New York: UNSCEAR.

UNSCEAR. 1982. Ionizing radiation: sources and biological effects. In: Report to the General Assembly, with annexes. United Nations, New York: UNSCEAR.

UNSCEAR. 1993. Sources and effects of ionizing radiation. In: Report to the General Assembly, with annexes. United Nations, New York: UNSCEAR.

Varga B, Tarján S, Süth M, Sas B. 2006. Radionuclide monitoring strategy for food-chain in Hungary. J. Environ. Radioact. 86: 1-11.

Cite this article as: Bartusková M, Škrkal J, Schlesingerová E, Bečková V, Malátová I. 2017. Doses from Cs-137 and Sr-90 to Czech population due to milk consumption. Radioprotection 52(3): 171-176 